\title{
The effects of pectin and rye on amino acid ileal digestibility, threonine metabolism, nitrogen retention, and morphology of the small intestine in young pigs*
}

\author{
E. Święch ${ }^{1}$, A. Tuśnio, M. Taciak, M. Boryczka and L. Buraczewska \\ The Kielanowski Institute of Animal Physiology and Nutrition, Polish Academy of Sciences \\ 05-110 Jablonna, Poland
}

(Received 29 November 2011; revised 14 February 2012; accepted 15 March 2012)

\begin{abstract}
The effects of supplementing cereal-based diets with 0,40 , or $80 \mathrm{~g}$ of pectin $(\mathrm{P})$ or $270 \mathrm{~g}$ of rye (R) per kg on ileal digestibility of protein and amino acids (AA), and digesta viscosity in pigs of 20 $\mathrm{kg}$ body weight (BW), and on growth performance, nitrogen balance, small intestinal morphology, and threonine metabolism parameters in pigs of $15 \mathrm{~kg}$ BW were assessed. Digesta viscosity was increased more by $80 \mathrm{~g}$ than by $40 \mathrm{~g}$ P or by R. Ileal digestibility of AA and nitrogen retention were negatively affected by $\mathrm{P}$, whereas growth performance was decreased by $\mathrm{R}$. The effect of the supplements on intestinal morphology was variable, except for the increase in myenteron thickness by $\mathrm{P}$ and crypt depth by $\mathrm{R}$. The number of goblet cells containing acidic mucins was decreased by $40 \mathrm{~g} \mathrm{P}$ in crypts in the mid-jejunum and by $40 \mathrm{~g} \mathrm{P}$ and $\mathrm{R}$ in villi in the ileum. Fasting and postprandial plasma levels of free threonine and of threonine dehydrogenase activity in the liver and pancreas were not affected. In conclusion, feeding $\mathrm{P}$ or R negatively affects ileal AA digestibility and provokes irregular changes of small intestinal morphology. These effects cannot be attributed to the increase of digesta viscosity as the main factor.
\end{abstract}

KEY WORDS: pigs, soluble NSP, ileal AA digestibility, threonine metabolism, nitrogen retention, intestinal morphology

\footnotetext{
* Presented in part at the $10^{\text {th }}$ International Symposium on Digestive Physiology in Pigs, May 2006, Vejle, Denmark, $3^{\text {rd }}$ Conference on Physiology and Biochemistry in Animal Nutrition, September 2006, Warsaw (Poland), and $2^{\text {nd }}$ International Symposium on Energy and Protein Metabolism and Nutrition, September 2007, Vichy (France)

${ }^{1}$ Corresponding author: e-mail: e.swiech@ifzz.pan.pl
} 


\section{INTRODUCTION}

Cereals contain nutritionally important amounts of non-starch polysaccharides (NSP) in both insoluble and soluble forms. The main components of rye and wheat NSP are arabinoxylans (pentosans) that constitute about $10 \%$ of dry matter in rye and 5.7 to $8.2 \%$ in wheat. Soluble NSP, in particular when provided in purified forms, increase digesta viscosity leading to slower absorption of amino acids (AA) and their lower ileal digestibility (Buraczewska, 2001; Wenk, 2001). Insoluble NSP reduce the transit time of digesta and are slowly degradable by the microflora in the large intestine (Buraczewska, 2001; Wenk, 2001). The study of Bartelt et al. (2002) showed that not only the viscosity-enhancing property of soluble NSP, but also other properties of complex dietary fibre, influencing digesta passage rate or bacterial activity, may contribute to changes in intestinal morphology, nutrient absorption, and endogenous nitrogen losses.

The results of several studies (Zhu, 2003; Myrie et al., 2006) showed that soluble NSP increase endogenous losses of AA, especially threonine (Thr), and affect utilization of this AA for protein deposition and growth. In consequence, the presence of soluble NSP in the diet of young pigs with a high lean gain potential may increase their Thr requirement. Large endogenous Thr losses are mainly due to the high Thr content in mucin proteins, which are very resistant to digestion. Mucins are secreted by goblet cells (GC) and protect the intestinal epithelium against bacterial, chemical, and mechanical injuries.

The aim of this study was to examine the response of young pigs to different types and levels of dietary NSP in terms of growth performance and protein utilization, and in relationship to the Thr metabolism and structure of the small intestine.

As the source of soluble NSP, highly esterified apple pectin $(\mathrm{P})$ and rye $(\mathrm{R})$ were compared. Growth performance, nitrogen retention, ileal digestibility of AA, concentration of free Thr and urea in blood plasma, threonine dehydrogenase (TDG) activity in the liver and pancreas, intestinal morphology, goblet cell number in the mid-jejunum and ileum were used as criteria.

\section{MATERIAL AND METHODS}

\section{Experimental design}

The experiments were approved by the Local Animal Care Committee. Two experiments were performed. In Experiment 1, apparent and standardized ileal digestibility (AID and SID, respectively) of protein and AA and ileal digesta viscosity were determined on cannulated pigs according to a cross-over design.In Experiment 2, nitrogen balance was determined twice in pigs from 
15 to $23 \mathrm{~kg}$ and from 24 to $33 \mathrm{~kg}$ of body weight (BW), and growth performance was measured during two 14-day periods. Blood was collected for free Thr and urea determination. After slaughter, tissue samples were taken for TDG and histological measurements.

\section{Animals and experimental procedures}

The experiments were performed on pigs with a high gain potential (390 g/ day from 25-100 kg BW, synthetic line 990, Mełno, Poland). Pigs were housed individually in metabolism cages in a thermally controlled room $\left(22-23^{\circ} \mathrm{C}\right)$ with free access to water.

In Experiment 1, AID and SID of protein and AA and ileal digesta viscosity were determined on twelve pigs with an initial BW of about $20 \mathrm{~kg}$. The pigs were surgically fitted with a post-valvular T-caecum cannula (PVTC) according to van Leeuwen et al. (1991). The recovery lasting 10 days was followed by 7-day periods of feeding the experimental diets. The feeding level was adjusted to $5 \%$ of BW corresponding to about $90 \%$ of ad libitum intake. The pigs were fed at 8.00 and $20.00 \mathrm{~h}$ with equal portions of meal diets mixed with water (1:1). During the last three days of experimental feeding, ileal digesta was collected from 8.00 to $20.00 \mathrm{~h}$, and viscosity was measured in a pooled sample of fresh digesta. The daily digesta were stored frozen and, after thawing, were pooled per animal within each experimental period and freeze dried for analysis.

In Experiment 2, twenty-four pigs were allocated into four groups (six pigs each), taking BW, age, and litters into account. After seven days of adaptation, the pigs were fed a starter diet with daily incremental additions of the test diets. Equal portions were given at $8.00,14.00$ and $20.00 \mathrm{~h}$, after mixing with water (1:1). Pigs (initially $15 \mathrm{~kg} \mathrm{BW}$ ) were fed experimental diets for 40 days. At a mean BW of approximately 20 and $30 \mathrm{~kg}$, the $\mathrm{N}$ balance was performed during two consecutive 14-day periods. The daily dietary allowance was provided at the rate of about $5 \%$ of BW, and was kept constant during the last nine days of $\mathrm{N}$ balance periods. Faeces and urine were collected for six days as described by Buraczewska et al. (2006).

Average daily gain $(\mathrm{ADG})$ and feed:gain ratio $(\mathrm{F} / \mathrm{G})$ were measured during two 14-day periods. Feeding experimental diets was continued for 12 days. After termination of the balance experiment, pigs were surgically implanted with catheters in the jugular vein. Blood sampling began three days after the surgery and lasted $6 \mathrm{~h}$. Samples were collected before and 0.5, 1, 2, 4 and $6 \mathrm{~h}$ after the morning meal. The pigs were slaughtered at about $40 \mathrm{~kg}$ of BW, the gastrointestinal tract was immediately removed and the small intestine dissected into the duodenum, jejunum and ileum. After rinsing with cold $0.9 \% \mathrm{NaCl}$, the segments were weighed and tissue samples were taken for histological parameters. The liver and pancreas were weighed and samples were taken and stored at $-80^{\circ} \mathrm{C}$ for determination of TDG activity. 


\section{Diets}

In Experiment 1, four cereal-based diets were used: control diet $\left(\mathrm{C}_{1}\right)$, two $\mathrm{C}_{1}$ diets supplemented with $40 \mathrm{~g}$ or $80 \mathrm{~g}$ of pectin per $\mathrm{kg}\left(\mathrm{C}_{1}+\mathrm{P} 40\right.$ and $\mathrm{C}_{1}+\mathrm{P} 80$, respectively), and one diet containing rye $\left(\mathrm{C}_{1}-\mathrm{R}\right)$. Diet $\mathrm{C}_{1}-\mathrm{R}$ was obtained by inclusion of $270 \mathrm{~g}$ of $\mathrm{R}$ and $30 \mathrm{~g}$ of full-fat soyabean into diet $\mathrm{C}_{1}$ instead of $300 \mathrm{~g}$ of wheat. The daily dietary allowance provided pigs with the same level of nutrients. Chromium oxide $\left(\mathrm{Cr}_{2} \mathrm{O}_{3}\right)$ was included as an indigestible marker. The composition of diets $\mathrm{C}_{1}$ and $\mathrm{C}_{1}-\mathrm{R}$ used in Experiment 1 is given in Table 1.

Table 1. Composition of the control diet $\left(\mathrm{C}_{1}\right)$ and the diet containing rye $\left(\mathrm{C}_{1}-\mathrm{R}\right)$ used in Experiment 1

\begin{tabular}{lrr}
\hline Item & $\mathrm{C}_{1}$ & Diets $^{1}$ \\
\cline { 2 - 3 } Ingredients, $g / \mathrm{kg}$ & & $\mathrm{C}_{1}-\mathrm{R}$ \\
wheat & 550.00 & 250.00 \\
rye & & 270.00 \\
maize & 150.00 & 150.00 \\
soyabean meal & 140.00 & 140.00 \\
full-fat soyabean & 90.00 & 120.00 \\
casein & 20.00 & 20.00 \\
dicalcium phosphate & 14.00 & 15.00 \\
limestone & 6.00 & 5.00 \\
salt & 3.00 & 3.00 \\
vitamin-mineral mixture ${ }^{2}$ & 5.83 & 5.83 \\
maize starch & 10.41 & 10.70 \\
L-lysine HCl (78\%) & 4.88 & 4.33 \\
L-threonine (98\%) & 1.67 & 1.59 \\
DL-methionine (98\%) & 1.21 & 1.55 \\
chromium oxide & 3.00 & 3.00 \\
Contents of nitrogen and amino acids, $g / k g$ & & \\
nitrogen & 31.20 & 30.30 \\
lysine & 13.47 & 13.76 \\
threonine & 8.16 & 8.34 \\
methionine & 4.25 & 4.37 \\
cysteine & 3.24 & 3.05 \\
tryptophan & 2.16 & 2.11 \\
isoleucine & 7.81 & 8.04 \\
arginine & 11.04 & 11.51 \\
histidine & 4.63 & 4.80 \\
leucine & 14.76 & 15.31 \\
phenylalanine & 9.17 & 9.24 \\
valine & 8.85 & 8.96 \\
\hline
\end{tabular}

${ }_{1} \mathrm{C}_{1}$ : control diet; $\mathrm{C}_{1}-\mathrm{R}$ : diet with rye obtained by inclusion to $1 \mathrm{~kg}$ of $\mathrm{C}_{1}$ diet $270 \mathrm{~g}$ rye and $30 \mathrm{~g}$ full-fat soyabean instead of $300 \mathrm{~g}$ wheat; diets $\mathrm{C}_{1}+\mathrm{P} 40$ and $\mathrm{C}_{1}+\mathrm{P} 80$ contained $\mathrm{C}_{1}$ diet additionally supplemented with 40 and $80 \mathrm{~g}$ apple pectin per $\mathrm{kg}$, respectively

2 provided per kg diet, IU: vit. A 15000 ; vit. $\mathrm{D}_{3} 2000$; $\mathrm{mg}$ : vit. E 60; vit. $\mathrm{B}_{1} 1$; vit. $\mathrm{B}_{2} 4$; biotin 0.25 ; vit. $\mathrm{B}_{6} 3$; vit. $\mathrm{B}_{12} 0.02$; vit. $\mathrm{K} 3$; niacin 20; folic acid 5; Ca pantothenian 15; choline 150; $\mathrm{Mg} 150$; Mn 50; Zn 150; Co 0.5; Se 0.3; Cu 150; Fe 125; I 1; g: Ca 1.3 
In Experiment 2, four cereal-based diets were used: $\mathrm{C}_{2}, \mathrm{C}_{2}+\mathrm{P} 40, \mathrm{C}_{2}+\mathrm{P} 80$, and $\mathrm{C}_{2}-\mathrm{R}$. Diets $\mathrm{C}_{2}$ and $\mathrm{C}_{2}-\mathrm{R}$ were formulated based on the SID of AA values in diets $\mathrm{C}_{1}$ and $\mathrm{C}_{1}-\mathrm{R}$ obtained in Experiment 1 and were supplemented with crystalline lysine, threonine, methionine, and tryptophan to cover the AA requirement of pigs during two experimental periods, below and over $23 \mathrm{~kg} \mathrm{BW}$. The composition of diets $\mathrm{C}_{2}$ and $\mathrm{C}_{2}-\mathrm{R}$ used in Experiment 2 is given in Table 2. Ileal digestibility of crystalline AA was assumed to be close to $100 \%$. Diets $\mathrm{C}_{2}+\mathrm{P} 40$ and $\mathrm{C}_{2}+\mathrm{P} 80$ were obtained by additional supplementation of diet $\mathrm{C}_{2}$ with $\mathrm{P} 40$ and $\mathrm{P} 80$ per kg diet, respectively. The metabolizable energy value of the diets calculated as $95 \%$ of digestible energy content was close to $14.0 \mathrm{MJ} \mathrm{ME} / \mathrm{kg}$.

\section{Chemical and histological analyses}

Dry matter in dietary ingredients and diets, and nitrogen $(\mathrm{N})$ in ingredients, diets, digesta, faeces and urine, were analysed using standard methods (AOAC, 1990). Chromic oxide was determined according to Kimura and Miller (1957). Amino acid analyses were performed with a Beckman high pressure System Gold AA analyzer (Beckman Instruments, Inc. Fullerton, CA, USA) using modified procedures according to Buraczewska and Buraczewski (1984).

Blood was collected into heparinized tubes and immediately centrifuged for $10 \mathrm{~min}$ at $3900 \mathrm{~g}$ at $4^{\circ} \mathrm{C}$. Plasma proteins were precipitated with salicylsulphonic acid and centrifuged for $10 \mathrm{~min}$ at $10000 \mathrm{~g}$ at $4^{\circ} \mathrm{C}$. Free $\mathrm{Thr}$ content was measured using gas chromatography (Hewlett Packard 5890 series II, Avondale, PA, USA) according to the method described by Hušek (1991) with modifications. Urea concentration was determined in pooled plasma samples taken at 2 and $4 \mathrm{~h}$ after the morning meal, using a biochemical diagnostic analyzer (Vitros DTII). Viscosity of digesta (after centrifugation for $15 \mathrm{~min}$ at $10,000 \mathrm{~g}$ ) was determined using a Brookfield DV-II+ digital viscosimeter (Brookfield Engineering Laboratories Inc., Stoughton, MA, USA) with a cone plate device (CP-40) at $40^{\circ} \mathrm{C}$. Tissue samples for histological analyses were placed in Bouin's solution, dehydrated and infiltrated with paraffin wax. Two slides were prepared from one sample, each slide containing a minimum of three sections cut at $5 \mu \mathrm{m}$. Sections were stained with haematoxylin and eosin, and villous length, crypt depth, and thickness of the tunica mucosa and myenteron were measured. The measurements of villous length and crypt depth were made on 30 well-oriented villi and 30 corresponding crypts. For the histological evaluation of gut mucins in the mid-jejunum and ileum, representative sections were stained with Alcian blue $\mathrm{pH}$ 2.5 (AB 2.5) for demonstration of acidic mucins and with periodic acid-Schiff base (PAS) for identification of neutral mucins. Goblet cells in the intestinal mucosa stained with AB 2.5 and PAS were counted in 10 well-oriented villi and 10 corresponding crypts. All measurements were performed using a light microscope (Zeiss type Axiostar Plus with Axio Vision LE Rel 4.5 software) with a 10 x or 5 x objective. 


\section{RESULTS}

Ileal digesta viscosity and ileal digestibility of amino acids (Experiment 1)

Effects of $\mathrm{P}$ and $\mathrm{R}$ on ileal digesta viscosity and $\mathrm{AA}$ ileal digestibility are presented in Table 3. Addition of $\mathrm{P} 40$ and $\mathrm{P} 80$ to diet $\mathrm{C}_{1}$ significantly increased digesta viscosity from 1.3 to 5.0 and to $87.8 \mathrm{mPa} \cdot \mathrm{s}$, respectively. The effect of dietary $\mathrm{R}$ on digesta viscosity was smaller $(2.1 \mathrm{vs} 1.3 \mathrm{mPa} \cdot \mathrm{s})$. Both $\mathrm{P}$ levels decreased the AID and SID of protein and AA $(\mathrm{P} \leq 0.01)$, however, only the AID of lysine, arginine, and histidine and the SID of arginine and histidine differed significantly between diets $\mathrm{C}_{1}+\mathrm{P} 40$ and $\mathrm{C}_{1}+\mathrm{P} 80$. The lowest digestibility values

Table 3. Ileal digesta viscosity ( $\mathrm{mPa} \cdot \mathrm{s})$ and ileal digestibility $(\%)$ of protein and amino acids; $\mathrm{n}=6$ (Experiment 1)

\begin{tabular}{|c|c|c|c|c|c|c|}
\hline \multirow[b]{2}{*}{ Item } & \multicolumn{4}{|c|}{ Diets $^{1}$} & \multirow{2}{*}{ SEM } & \multirow{2}{*}{$\mathrm{P}$} \\
\hline & $\mathrm{C}_{1}$ & $\mathrm{C}_{1}+\mathrm{P} 40$ & $\mathrm{C}_{1}+\mathrm{P} 80$ & $\mathrm{C}_{1}-\mathrm{R}$ & & \\
\hline Viscosity & $1.32^{\mathrm{a}}$ & $4.95^{\mathrm{c}}$ & $87.78^{\mathrm{d}}$ & $2.06^{\mathrm{b}}$ & 7.22 & 0.05 \\
\hline \multicolumn{7}{|c|}{ Apparent ileal digestibility } \\
\hline Protein & $77.3^{\mathrm{b}}$ & $71.6^{\mathrm{a}}$ & $69.8^{\mathrm{a}}$ & $75.6^{\mathrm{b}}$ & 0.7 & $<0.001$ \\
\hline Lys & $79.7^{\mathrm{c}}$ & $73.3^{\mathrm{b}}$ & $70.1^{\mathrm{a}}$ & $78.6^{\mathrm{c}}$ & 0.5 & $<0.001$ \\
\hline Thr & $71.7^{\mathrm{b}}$ & $63.9^{\mathrm{a}}$ & $63.0^{\mathrm{a}}$ & $71.3^{\mathrm{b}}$ & 0.8 & $<0.001$ \\
\hline Met & $83.3^{\mathrm{c}}-\mathrm{r}-\mathrm{k}-\mathrm{k}$ & $77.9^{\mathrm{ab}}$ & $74.9^{\mathrm{a}}$ & $80.4^{\mathrm{bc}}$ & 0.5 & $<0.001$ \\
\hline Cys & $68.7^{\mathrm{b}}$ & $60.2^{\mathrm{a}}$ & $57.3^{\mathrm{a}}$ & $64.1^{\mathrm{b}}$ & 1.8 & 0.002 \\
\hline Trp & $76.1^{\mathrm{b}}$ & $70.3^{\mathrm{a}}$ & $69.5^{\mathrm{a}}$ & $73.8^{\mathrm{ab}}$ & 1.1 & $<0.001$ \\
\hline Ile & $78.1^{\mathrm{b}}$ & $73.1^{\mathrm{a}}$ & $71.5^{\mathrm{a}}$ & $77.3^{\mathrm{b}}$ & 0.6 & $<0.001$ \\
\hline Arg & $86.7^{\mathrm{c}}$ & $83.5^{\mathrm{b}}$ & $81.0^{\mathrm{a}}$ & $86.2^{\mathrm{c}}$ & 0.5 & $<0.001$ \\
\hline His & $83.4^{\mathrm{c}}$ & $78.2^{\mathrm{b}}$ & $75.4^{\mathrm{a}}$ & $82.6^{\mathrm{c}}$ & 0.6 & $<0.001$ \\
\hline Leu & $80.5^{\mathrm{b}}$ & $76.1^{\mathrm{a}}$ & $74.8^{\mathrm{a}}$ & $79.9^{\mathrm{b}}$ & 0.7 & $<0.001$ \\
\hline Phe & $81.8^{\mathrm{b}}$ & $77.4^{\mathrm{a}}$ & $75.8^{\mathrm{a}}$ & $80.6^{\mathrm{b}}$ & 0.6 & $<0.001$ \\
\hline Val & $78.9^{\mathrm{b}}$ & $73.5^{\mathrm{a}}$ & $72.0^{\mathrm{a}}$ & $77.6^{\mathrm{b}}$ & 0.6 & $<0.001$ \\
\hline \multicolumn{7}{|c|}{ Standardized ileal diestibility } \\
\hline Protein & $83.5^{\mathrm{b}}$ & $78.0^{\mathrm{a}}$ & $76.5^{\mathrm{a}}$ & $81.7^{\mathrm{b}}$ & 0.7 & $<0.001$ \\
\hline Lys & $83.8^{\mathrm{b}}$ & $77.8^{\mathrm{a}}$ & $74.9^{\mathrm{a}}$ & $82.6^{\mathrm{b}}$ & 0.5 & $<0.001$ \\
\hline Thr & $81.1^{\mathrm{b}}$ & $74.0^{\mathrm{a}}$ & $73.7^{\mathrm{a}}$ & $80.3^{\mathrm{b}}$ & 0.8 & $<0.001$ \\
\hline Met & $86.9^{\mathrm{b}}$ & $81.9^{\mathrm{a}}$ & $79.0^{\mathrm{a}}$ & $84.3^{\mathrm{b}}$ & 0.5 & $<0.001$ \\
\hline Cys & $75.3^{b}$ & $67.1^{\mathrm{a}}$ & $64.5^{\mathrm{a}}$ & $71.0^{\mathrm{ab}}$ & 1.8 & $<0.001$ \\
\hline Trp & $82.7^{\mathrm{b}}$ & $77.2^{\mathrm{a}}$ & $76.7^{\mathrm{a}}$ & $80.4^{\mathrm{ab}}$ & 1.1 & 0.003 \\
\hline Ile & $83.1^{\mathrm{b}}$ & $78.2^{\mathrm{a}}$ & $76.8^{\mathrm{a}}$ & $82.1^{\mathrm{b}}$ & 0.6 & $<0.001$ \\
\hline Arg & $90.3^{c}$ & $87.2^{\mathrm{b}}$ & $84.9^{\mathrm{a}}$ & $89.6^{c}$ & 0.5 & $<0.001$ \\
\hline His & $87.5^{\mathrm{c}}$ & $82.6^{\mathrm{b}}$ & $79.9^{\mathrm{a}}$ & $86.6^{c}$ & 0.6 & $<0.001$ \\
\hline Leu & $83.9^{b}$ & $79.6^{\mathrm{a}}$ & $78.5^{\mathrm{a}}$ & $83.1^{\mathrm{b}}$ & 0.7 & $<0.001$ \\
\hline Phe & $85.5^{b}$ & $81.3^{\mathrm{a}}$ & $79.9^{\mathrm{a}}$ & $84.3^{\mathrm{b}}$ & 0.6 & $<0.001$ \\
\hline Val & $85.0^{\mathrm{b}}$ & $80.0^{\mathrm{a}}$ & $78.7^{\mathrm{a}}$ & $83.6^{\mathrm{b}}$ & 0.6 & $<0.001$ \\
\hline
\end{tabular}


were found for cystine and threonine. Inclusion of $\mathrm{R}$ in the diet somewhat decreased all values of AID and SID of protein and AA, however, the differences between diets $\mathrm{C}_{1}$ and $\mathrm{C}_{1}-\mathrm{R}$ were not significant.

Growth performance, nitrogen retention and urea content in plasma (Experiment 2)

The growth performance results are presented in Table 4. In the first period, $\mathrm{P}$ supplementation tended to decrease ADG from 589 to 556 and $565 \mathrm{~g}$, and to increase the $\mathrm{F} / \mathrm{G}$ ratio from 1.40 to 1.49 and 1.47 for $\mathrm{P} 40$ and $\mathrm{P} 80$, respectively.

Table 4. Growth performance in pigs during the first (1-14 d) and second (15-28 d) periods; $n=6$ (Experiment 2)

\begin{tabular}{|c|c|c|c|c|c|c|}
\hline \multirow{2}{*}{ Item } & \multicolumn{4}{|c|}{ Diets $^{1}$} & \multirow[b]{2}{*}{ SEM } & \multirow[b]{2}{*}{$\mathrm{P}$} \\
\hline & $\mathrm{C}_{2}$ & $\mathrm{C}_{2}+\mathrm{P} 40$ & $\mathrm{C}_{2}+\mathrm{P} 80$ & $\mathrm{C}_{2}-\mathrm{R}$ & & \\
\hline Initial BW, kg & 14.8 & 14.8 & 15.1 & 15.3 & 0.32 & \\
\hline \multicolumn{7}{|l|}{ Average daily gain, $g$} \\
\hline $1-14 d$ & $589^{b}$ & $556^{\mathrm{ab}}$ & $565^{\mathrm{ab}}$ & $530^{\mathrm{a}}$ & 12.7 & 0.022 \\
\hline $15-28 d$ & 727 & 686 & 728 & 717 & 14.2 & 0.206 \\
\hline \multicolumn{7}{|l|}{ Feed/gain ratio, $\mathrm{kg} / \mathrm{kg}^{2}$} \\
\hline $1-14 d$ & $1.40^{\mathrm{a}}$ & $1.49^{\mathrm{a}}$ & $1.47^{\mathrm{a}}$ & $1.57^{\mathrm{b}}$ & 0.04 & 0.015 \\
\hline $15-28 \mathrm{~d}$ & 1.63 & 1.71 & 1.61 & 1.64 & 0.03 & 0.286 \\
\hline \multicolumn{7}{|c|}{$\begin{array}{l}{ }^{1} \mathrm{C}_{2} \text { : control diet; } \mathrm{C}_{2}+\mathrm{P} 40 \text { and } \mathrm{C}_{2}+\mathrm{P} 80 \text { : diet } \mathrm{C}_{2} \text { additionally supplemented with } \\
\text { apple pectin per } \mathrm{kg} \text {, respectively; } \mathrm{C}_{2}-\mathrm{R} \text { : diet with rye obtained by inclusion to } \\
270 \mathrm{~g} \text { rye and } 30 \mathrm{~g} \text { full-fat soyabean instead of } 300 \mathrm{~g} \text { wheat } \\
{ }^{2} \text { feed/gain ratio was calculated taking into account intake of feed without pectin } \\
\text { means in the same row with different superscripts differ at } \mathrm{P} \leq 0.05\end{array}$} \\
\hline
\end{tabular}

In the second period, no significant effect of $\mathrm{P}$ on $\mathrm{ADG}$ and $\mathrm{F} / \mathrm{G}$ ratio was observed. Inclusion of $\mathrm{R}$ in diet $\mathrm{C}_{2}$ significantly decreased ADG (530 vs 589 g) and increased the $F / G$ ratio (1.57 vs 1.40$)$, but only in the first period. The results of $\mathrm{N}$ balance and urea level are shown in Table 5. In the first balance period, significant increases of daily faecal and total $\mathrm{N}$ excretion (4.9 vs $3.5 \mathrm{~g}$ and 10.5 vs 9.6 g, respectively) and decrease of $\mathrm{N}$ retention $(60.2$ vs $63.6 \%$ of $\mathrm{N}$ intake) were found in pigs fed $\operatorname{diet} \mathrm{C}_{2}+\mathrm{P} 80$, compared with diet $\mathrm{C}_{2}$. In the second balance period, both $\mathrm{P}$ levels significantly increased daily faecal $\mathrm{N}$ excretion (from 4.5 to 6.5 and $7.2 \mathrm{~g}$, respectively), increased or tended to increase daily total $\mathrm{N}$ excretion (from 14.7 to 15.9 and $15.7 \mathrm{~g}$, respectively), and decreased $\mathrm{N}$ retention (from 60.4 to 57.3 and $57.6 \%$ of $\mathrm{N}$ intake, respectively). No significant effect of $\mathrm{R}$ inclusion on $\mathrm{N}$ excretion and $\mathrm{N}$ retention was found. A tendency to lower urinary $\mathrm{N}$ excretion in pigs fed diets supplemented with $\mathrm{P}$ and $\mathrm{R}$ was observed in both balance periods. 
Table 5. Nitrogen balance and urea concentration in blood plasma; $n=6$ (Experiment 2 )

\begin{tabular}{|c|c|c|c|c|c|c|}
\hline \multirow[b]{2}{*}{ Item } & \multicolumn{4}{|c|}{ Diets $^{1}$} & \multirow[b]{2}{*}{ SEM } & \multirow[b]{2}{*}{$\mathrm{P}$} \\
\hline & $\mathrm{C}_{2}$ & $\mathrm{C}_{2}+\mathrm{P} 40$ & $\mathrm{C}_{2}+\mathrm{P} 80$ & $\mathrm{C}_{2}-\mathrm{R}$ & & \\
\hline \multicolumn{7}{|l|}{ Balance 1, pigs about $20 \mathrm{~kg} \mathrm{BW}$} \\
\hline $\mathrm{N}$ intake, $\mathrm{g} / \mathrm{d}$ & 26.4 & 26.4 & 26.4 & 26.0 & & \\
\hline urinary $\mathrm{N}$ excretion, $\mathrm{g} / \mathrm{d}$ & 6.1 & 6.0 & 5.6 & 5.4 & 0.33 & 0.383 \\
\hline faecal $\mathrm{N}$ excretion, $\mathrm{g} / \mathrm{d}$ & $3.5^{\mathrm{a}}$ & $4.2^{\mathrm{ab}}$ & $4.9^{\mathrm{b}}$ & $4.2^{\mathrm{ab}}$ & 1.05 & 0.002 \\
\hline total $\mathrm{N}$ excretion, $\mathrm{g} / \mathrm{d}$ & $9.6^{\mathrm{a}}$ & $10.2^{\mathrm{ab}}$ & $10.5^{\mathrm{b}}$ & $9.6^{\mathrm{a}}$ & 0.17 & 0.011 \\
\hline $\mathrm{N}$ retention, $\mathrm{g} / \mathrm{d}$ & $16.8^{\mathrm{b}}$ & $16.2^{\mathrm{b}}$ & $15.9^{\mathrm{a}}$ & $16.4^{\mathrm{b}}$ & 0.19 & 0.015 \\
\hline protein digestibility $^{2}, \%$ & $86.7^{\mathrm{b}}$ & $84.0^{\mathrm{ab}}$ & $81.3^{\mathrm{a}}$ & $83.9^{\mathrm{ab}}$ & 0.85 & 0.002 \\
\hline $\mathrm{N}$ retention, $\% \mathrm{~N}$ intake & $63.6^{\mathrm{b}}$ & $61.4^{\mathrm{ab}}$ & $60.2^{\mathrm{a}}$ & $63.1^{\mathrm{b}}$ & 0.71 & 0.007 \\
\hline $\mathrm{N}$ retention, $\% \mathrm{~N}$ absorbed & 73.4 & 73.1 & 74.1 & 75.4 & 1.28 & 0.590 \\
\hline \multicolumn{7}{|l|}{ Balance 1, pigs about $30 \mathrm{~kg} \mathrm{BW}$} \\
\hline $\mathrm{N}$ intake, $\mathrm{g} / \mathrm{d}$ & 37.2 & 37.2 & 37.2 & 36.4 & & \\
\hline urinary $\mathrm{N}$ excretion, $\mathrm{g} / \mathrm{d}$ & 10.3 & 9.4 & 8.5 & 9.5 & 0.41 & 0.062 \\
\hline faecal $\mathrm{N}$ excretion, $\mathrm{g} / \mathrm{d}$ & $4.5^{\mathrm{a}}$ & $6.5^{\mathrm{b}}$ & $7.2^{\mathrm{c}}$ & $5.4^{\mathrm{ab}}$ & 0.30 & $<0.001$ \\
\hline total $\mathrm{N}$ excretion, $\mathrm{g} / \mathrm{d}$ & $14.7^{\mathrm{a}}$ & $15.9^{\mathrm{b}}$ & $15.7^{\mathrm{ab}}$ & $14.9^{\mathrm{ab}}$ & 0.29 & 0.023 \\
\hline $\mathrm{N}$ retention, $\mathrm{g} / \mathrm{d}$ & $22.5^{\mathrm{b}}$ & $21.3^{\mathrm{a}}$ & $21.4^{\mathrm{a}}$ & $21.5^{\mathrm{ab}}$ & 0.30 & 0.027 \\
\hline protein digestibility $^{2}, \%$ & $88.0^{\mathrm{c}}$ & $82.5^{\mathrm{ab}}$ & $80.5^{\mathrm{a}}$ & $85.1^{\mathrm{bc}}$ & 0.72 & $<0.001$ \\
\hline $\mathrm{N}$ retention, $\% \mathrm{~N}$ intake & $60.4^{\mathrm{b}}$ & $57.3^{\mathrm{a}}$ & $57.6^{\mathrm{a}}$ & $58.9^{\mathrm{b}}$ & 0.80 & 0.040 \\
\hline $\mathrm{N}$ retention, $\% \mathrm{~N}$ absorbed & 68.6 & 69.5 & 71.5 & 69.2 & 1.14 & 0.199 \\
\hline Urea in plasma, mmol/1 & $3.01^{\mathrm{b}}$ & $2.85^{\mathrm{b}}$ & $2.13^{\mathrm{a}}$ & $2.98^{b}$ & 0.22 & 0.049 \\
\hline
\end{tabular}

${ }^{1}$ as in Table $4 ;{ }^{2}$ total tract digestibility of protein

means in the same row with different superscripts differ at $\mathrm{P} \leq 0.05$

Plasma urea concentration was decreased by added $\mathrm{P}$, but only the difference between pigs fed diets $\mathrm{C}_{2}$ and $\mathrm{C}_{2}+\mathrm{P} 80$ was significant (Table 5). Inclusion of $\mathrm{R}$ in $\mathrm{C}_{2}$ diet did not affect urea concentration.

Free threonine in plasma and threonine dehydrogenase activity in liver and pancreas (Experiment 2)

The concentration of free Thr in plasma of fasted animals and its changes during six $\mathrm{h}$ after the morning meal are shown in Figure 1. At no sampling time Thr levels differed significantly among the treatments, but in all of the samples taken after the meal they were the highest on $\operatorname{diet} \mathrm{C}_{2}+\mathrm{P} 40$. The concentration of the AA increased after the meal until the first hour in animals fed on all diets and until the second hour on diets $\mathrm{C}_{2}-\mathrm{R}$ and $\mathrm{C}_{2}+\mathrm{P} 40$. After $6 \mathrm{~h}$, free Thr concentrations were close to fasting levels.

The experimental diets had no effect on liver and pancreas weights (data not shown). TDG activity was higher in the pancreas than in the liver (Table 6) and was not affected by the diet. A tendency towards lower pancreatic values in animals fed diets supplemented with $\mathrm{P}$ and $\mathrm{R}$ than in the control pigs $(0.62,0.52$ and $0.51 \mathrm{vs} 0.70 \mu \mathrm{mol} / \mathrm{min} / \mathrm{g}$, respectively), can be noticed, however. 


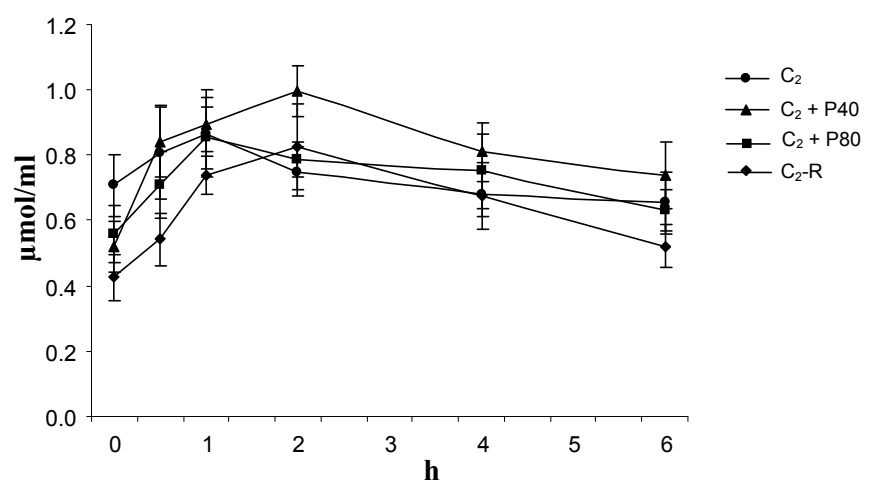

Figure 1. Threonine concentration in plasma $(\mu \mathrm{mol} / \mathrm{ml})$ of pigs fed different experimental diets, $\mathrm{n}=6$ (Experiment 2): $\mathrm{C}_{2}$ : control diet; $\mathrm{C}_{2}+\mathrm{P} 40$ and $\mathrm{C}_{2}+\mathrm{P} 80$ : control diet additionally supplemented with $40 \mathrm{~g}$ and $80 \mathrm{~g}$ apple pectin per $\mathrm{kg}$, respectively; $\mathrm{C}_{2}-\mathrm{R}$ : diet with rye obtained by inclusion to $1 \mathrm{~kg}$ of $\mathrm{C}_{2}$ diet $270 \mathrm{~g}$ rye and $30 \mathrm{~g}$ full-fat soyabean instead of $300 \mathrm{~g}$ wheat

Table 6. Threonine dehydrogenase activity in the liver and pancreas, $\mu \mathrm{mol} / \mathrm{min} / \mathrm{g} ; \mathrm{n}=6$ (Experiment 2 )

\begin{tabular}{|c|c|c|c|c|c|c|}
\hline \multirow[b]{2}{*}{ Item } & \multicolumn{4}{|c|}{ Diets $^{1}$} & \multirow[b]{2}{*}{ SEM } & \multirow[b]{2}{*}{$\mathrm{P}$} \\
\hline & $\mathrm{C}_{2}$ & $\mathrm{C}_{2}+\mathrm{P} 40$ & $\mathrm{C}_{2}+\mathrm{P} 80$ & $\mathrm{C}_{2}-\mathrm{R}$ & & \\
\hline Liver & 0.38 & 0.40 & 0.33 & 0.30 & 0.05 & 0.559 \\
\hline Pancreas & 0.70 & 0.62 & 0.52 & 0.51 & 0.07 & 0.115 \\
\hline
\end{tabular}

${ }^{1}$ see Table 4

means in the same row with different superscripts differ at $\mathrm{P} \leq 0.05$

\section{Morphology of the small intestine (Experiment 2)}

The experimental diets had no effect on the weights of the small intestine segments (data not shown), but they modified their morphometry (Table 7). Villi length was affected by the P level in different ways: P40 decreased villi length in the duodenum (from 347 to $330 \mu \mathrm{m}$ ), whereas P80 increased its length in the ileum (from 331 to $375 \mu \mathrm{m}$ ). Villi surface area was significantly larger in the mid-jejunum of pigs fed diets with both $\mathrm{P}$ levels $(0.25$ and 0.27 vs $0.21 \mathrm{~mm}^{2}$, respectively) and in the ileum in pigs fed the diet with P40 $\left(0.24\right.$ vs $\left.0.20 \mathrm{~mm}^{2}\right)$. Crypt depth was smaller in the mid-jejunum in pigs fed the diet containing P40 (240 vs $267 \mu \mathrm{m})$ and in the ileum of pigs fed the diet containing P80 (232 vs $248 \mu \mathrm{m})$. The villi length to crypt depth ratio was affected by P in an irregular way. The tunica mucosa was significantly thinner in the mid-jejunum of pigs fed diet $\mathrm{C}_{2}+\mathrm{P} 40$ (676 vs $705 \mu \mathrm{m}$ ). Myenteron thickness was the greatest $(\mathrm{P} \leq 0.001)$ in all segments in pigs fed diets with $\mathrm{P}$ in comparison with the other diets. 
Table 7. Measurements of histological parameters of different parts of the small intestine; $\mu \mathrm{m} ; \mathrm{n}=6$ (Experiment 2)

\begin{tabular}{|c|c|c|c|c|c|c|}
\hline \multirow{2}{*}{ Item } & \multicolumn{4}{|c|}{ Diets $^{1}$} & \multirow{2}{*}{ SEM } & \multirow{2}{*}{$\mathrm{P}$} \\
\hline & $\mathrm{C}_{2}$ & $\mathrm{C}_{2}+\mathrm{P} 40$ & $\mathrm{C}_{2}+\mathrm{P} 80$ & $\mathrm{C}_{2}-\mathrm{R}$ & & \\
\hline \multicolumn{7}{|l|}{ Villi length, $\mu m$} \\
\hline duodenum & $347^{\mathrm{b}}$ & $330^{\mathrm{a}}$ & $352^{\mathrm{b}}$ & $355^{\mathrm{ab}}$ & 6 & 0.041 \\
\hline mid-jejunum & $373^{\mathrm{a}}$ & $367^{\mathrm{a}}$ & $386^{\mathrm{a}}$ & $424^{b}$ & 7 & $<0.001$ \\
\hline ileum & $331^{\mathrm{a}}$ & $325^{\mathrm{a}}$ & $375^{b}$ & $336^{\mathrm{a}}$ & 6 & $<0.001$ \\
\hline \multicolumn{7}{|c|}{ Villi surface area, $\mathrm{mm}^{2}$} \\
\hline duodenum & 0.23 & 0.24 & 0.25 & 0.25 & 0.01 & 0.055 \\
\hline mid-jejunum & $0.21^{\mathrm{a}}$ & $0.25^{\mathrm{b}}$ & $0.27^{\mathrm{b}}$ & $0.26^{\mathrm{b}}$ & 0.01 & $<0.001$ \\
\hline ileum & $0.20^{\mathrm{a}}$ & $0.24^{\mathrm{b}}$ & $0.21^{\mathrm{a}}$ & $0.23^{\mathrm{b}}$ & 0.01 & $<0.001$ \\
\hline \multicolumn{7}{|l|}{ Crypt depth, $\mu m$} \\
\hline duodenum & $314^{\mathrm{a}}$ & $335^{\mathrm{a}}$ & $320^{\mathrm{a}}$ & $392^{\mathrm{b}}$ & 8 & $<0.001$ \\
\hline mid-jejunum & $267^{b}$ & $240^{\mathrm{a}}$ & $251^{\mathrm{ab}}$ & $315^{\mathrm{c}}$ & 6 & $<0.001$ \\
\hline ileum & $248^{\mathrm{b}}$ & $262^{\mathrm{b}}$ & $232^{\mathrm{a}}$ & $305^{\mathrm{c}}$ & 6 & $<0.001$ \\
\hline \multicolumn{7}{|c|}{ Villi length to crypt depth ratio } \\
\hline duodenum & $1.21^{\mathrm{c}}$ & $1.09^{\mathrm{b}}$ & $1.18^{\mathrm{c}}$ & $0.94^{\mathrm{a}}$ & 0.04 & $<0.001$ \\
\hline mid-jejunum & $1.48^{\mathrm{a}}$ & $1.66^{\mathrm{b}}$ & $1.64^{\mathrm{b}}$ & $1.40^{\mathrm{a}}$ & 0.06 & $<0.001$ \\
\hline ileum & $1.43^{\mathrm{c}}$ & $1.32^{\mathrm{b}}$ & $1.72^{\mathrm{d}}$ & $1.15^{\mathrm{a}}$ & 0.04 & $<0.001$ \\
\hline \multicolumn{7}{|c|}{ Tunica mисоsa thickness, $\mu$ m } \\
\hline duodenum & $752^{\mathrm{ab}}$ & $755^{\mathrm{ab}}$ & $729^{a}$ & $805^{\mathrm{b}}$ & 11 & 0.038 \\
\hline mid-jejunum & $705^{b}$ & $676^{\mathrm{a}}$ & $694^{\mathrm{ab}}$ & $781^{\mathrm{c}}$ & 9 & $<0.001$ \\
\hline ileum & 644 & 650 & 654 & 671 & 9 & 0.098 \\
\hline \multicolumn{7}{|c|}{ Myenteron thickness, $\mu \mathrm{m}$} \\
\hline duodenum & $556^{\mathrm{ab}}$ & $635^{\mathrm{c}}$ & $569^{\mathrm{b}}$ & $559^{a}$ & 12 & $<0.001$ \\
\hline mid-jejunum & $359^{a}$ & $443^{c}$ & $421^{b}$ & $374^{\mathrm{a}}$ & 8 & $<0.001$ \\
\hline ileum & $707^{\mathrm{a}}$ & $819^{b}$ & $818^{\mathrm{b}}$ & $728^{\mathrm{a}}$ & 14 & $<0.001$ \\
\hline
\end{tabular}

1 as in Table 4

means in the same row with different superscripts differ at $\mathrm{P} \leq 0.05$

In comparison with all $\mathrm{C}_{2}$ diets, $\mathrm{R}$ inclusion significantly increased villi length in the mid-jejunum (424 vs 367-386 $\mu \mathrm{m}$ ) and crypt depth in all intestinal segments. Therefore, the villi length to crypt depth ratio showed the lowest values in all segments $(\mathrm{P} \leq 0.001)$. Tunica mucosa thickness was significantly increased in the mid-jejunum in pigs fed R (from 705 to $781 \mu \mathrm{m}$ ). Similarly to P, addition of $\mathrm{R}$ also increased villi surface in the mid-jejunum (from $0.21 \mathrm{vs}$ to $0.26 \mathrm{~mm}^{2}$ ) and ileum (from 0.20 to $0.23 \mathrm{~mm}^{2}$ ) as compared with $\operatorname{diet} \mathrm{C}_{2}$.

Goblet cell number in the small intestine (Experiment 2)

The effects of $\mathrm{P}$ and $\mathrm{R}$ on the number of $\mathrm{GC}$ containing acidic and neutral mucins in the mid-jejunum and ileum are presented in Table 8 . In the mid-jejunum, the number of acidic type GC in crypts was decreased by P40 supplementation 
(5.9 vs 7.6-8.0 GC/crypt) as compared with the other diets. In the ileum, however, feeding pigs with $\mathrm{P} 40$ and $\mathrm{R}$ decreased the number of $\mathrm{GC}$ containing acidic mucins in villi (from 15.2 to 12.2 and 12.8, GC/villous, respectively). Addition of P80 affected only the number of GC containing neutral mucins in crypts in the ileum, which increased (from 15.7-16.8 to $20.1 \mathrm{GC} / \mathrm{crypt}$ ) in comparison with the other treatments.

Table 8. Goblet cell number containing neutral or acidic mucins per villous and per crypt in the midjejunum and ileum; $n=6$ (Experiment 2$)$

\begin{tabular}{|c|c|c|c|c|c|c|}
\hline \multirow{2}{*}{ Type of mucin } & \multicolumn{4}{|c|}{ Diets $^{1}$} & \multirow{2}{*}{ SEM } & \multirow{2}{*}{$\mathrm{P}$} \\
\hline & $\mathrm{C}_{2}$ & $\mathrm{C}_{2}+\mathrm{P} 40$ & $\mathrm{C}_{2}+\mathrm{P} 80$ & $\mathrm{C}_{2}-\mathrm{R}$ & & \\
\hline \multicolumn{7}{|l|}{$\overline{\text { Acidic }}$} \\
\hline \multicolumn{7}{|l|}{ mid-jejunum } \\
\hline villi & 9.6 & 8.6 & 10.2 & 10.2 & 0.56 & 0.498 \\
\hline crypts & $8.0^{\mathrm{b}}$ & $5.9^{\mathrm{a}}$ & $7.7^{\mathrm{b}}$ & $7.6^{\mathrm{b}}$ & 0.37 & $<0.001$ \\
\hline \multicolumn{7}{|l|}{ ileum } \\
\hline villi & $15.2^{\mathrm{c}}$ & $12.2^{\mathrm{a}}$ & $13.4^{\mathrm{bc}}$ & $12.8^{\mathrm{ab}}$ & 0.94 & 0.006 \\
\hline crypts & 16.9 & 17.4 & 16.1 & 15.9 & 0.82 & 0.626 \\
\hline \multicolumn{7}{|l|}{ Neutral } \\
\hline \multicolumn{7}{|l|}{ mid-jejunum } \\
\hline villi & 8.6 & 9.0 & 10.6 & 9.8 & 0.54 & 0.182 \\
\hline crypts & 4.7 & 4.9 & 4.9 & 5.4 & 0.23 & 0.179 \\
\hline \multicolumn{7}{|l|}{ ileum } \\
\hline villi & 14.6 & 13.2 & 14.0 & 11.6 & 0.86 & 0.055 \\
\hline crypts & $16.3^{\mathrm{a}}$ & $16.8^{\mathrm{a}}$ & $20.1^{\mathrm{b}}$ & $15.7^{\mathrm{a}}$ & 0.77 & 0.004 \\
\hline
\end{tabular}

${ }^{1}$ as in Table 4

means in the same row with different superscripts differ at $\mathrm{P} \leq 0.05$

\section{DISCUSSION}

In the present study, the effects of supplementing an AA-balanced cerealbased diet with two amounts of pectin $(\mathrm{P})$ or substitution of part of wheat by rye (R) were not uniform, as both types of supplement and P level affected many evaluated parameters differently. This general finding is in agreement with investigations showing that the effects of dietary fibre differ with the source, quantity, and nature of the fibre and are related to its chemical composition and physicochemical properties. The different responses to $\mathrm{R}$ and $\mathrm{P}$ may therefore be ascribed to their diverse chemical structure and characteristics of NSP. The nonstarch polysaccharides present in $\mathrm{R}$ are a mixture of polysaccharides classified as cell-wall NSP, i.e. mixed linked $\beta$-glucans with glucose as a monomeric residue, and of non-cell-wall NSP, mainly fructans yielding fructose, whereas those in $\mathrm{P}$ are classified as non-cell-wall NSP composed of uronic acids and rhamnose (Montagne et al., 2003). 
In our study, ileal digestibility of all AA was depressed by $\mathrm{P}$, but the response was not proportional to the amount added to the diet. The differences in AID and SID values were considerably greater between pigs fed on diets $\mathrm{C}_{1}$ and $\mathrm{C}_{1}+\mathrm{P} 40$ than between animals fed the diets with the lower and higher $\mathrm{P}$ supplement. The negative effect of P on AID and SID is consistent with the results of experiments on young and adult pigs presented by Mosenthin et al. (1994) and Zhu (2003).

Replacing part of the wheat with $\mathrm{R}$ also decreased the ileal digestibility of protein and AA, however, to a smaller extent than P. The lower ileal digestibility of $\mathrm{R}$ than wheat protein is in agreement with data reported by Buraczewska (2001), who also indicated that the AID of R protein is related to the soluble dietary fibre content and viscosity of this cereal.

The increase of digesta viscosity by soluble NSP is often considered to be the main factor responsible for lower ileal digestibility of protein due to the reduced mixing rate of digesta and diffusion of particles, and the formation of complexes with digestive enzymes. The results of some experiments reviewed by Souffrant (2001) do not confirm this relationship, however. Also in our experiment the considerable decrease of ileal protein digestibility at the lower P supplement was accompanied by an only minor increase of digesta viscosity and, in contrast, the high digesta viscosity induced by the greater amount of $\mathrm{P}$ was accompanied by a relatively small decrease of digestibility. This discrepancy between the effects of $\mathrm{P}$ on viscosity and ileal digestibility seems to confirm the assumption that the negative effect of $\mathrm{P}$ on ileal digestibility is also related to other factors, such as increased endogenous nitrogen losses and microbial fermentation in the gut (Schulze et al., 1995; McCullough et al., 1998) as well as digesta passage rate (Bartelt et al., 2002), which contribute to changes in the digestibility of nutrients, their absorption, and utilization.

The results of Experiment 2 confirm the negative effect of P not only on ileal, but also on total tract protein digestibility, the effect of $\mathrm{P}$ level being more uniform in younger than in older pigs. The increase of faecal nitrogen excretion due to P may reflect not only a lower degree of enzymatic protein digestion in the small intestine, but also more intensive synthesis of bacterial protein in the large intestine.

Inclusion of $\mathrm{R}$ into the $\mathrm{C}_{2}$ diet slightly depressed total tract digestibility of protein in younger and older pigs, but the differences were not significant.

In agreement with decreased total tract protein digestibility, nitrogen retention was lowered by P supplementation. Nevertheless, utilization of absorbed nitrogen was not affected by $\mathrm{P}$ in younger pigs, whereas in older animals it tended to be even slightly improved. This finding is the opposite of the expected deterioration of protein utilization of $\mathrm{P}$-containing diets due to their lower ileal protein digestibility and smaller content of ileal digestible essential AA, since only diets $\mathrm{C}_{2}$ and $\mathrm{C}_{2}-\mathrm{R}$ were supplemented with four limiting AA according to their actual SID contents 
determined in Experiment 1. The possible explanation may the apparently excessive level of AA supplementation of the control diet according to proposals given by Rademacher et al. (1999), probably providing sufficient amounts of SID AA also to the P-containing diets, in spite of their lower ileal digestibility. The actual dietary contents of SID AA covered the requirement given by NRC (1998), except for the marginally lower tryptophan concentration. A slight decrease of urinary nitrogen excretion and improvement in the utilization of absorbed nitrogen was accompanied by a lower plasma urea concentration (significant for the higher P supplementation). Such effects of fermentable NSP, often found in monogastric animals, point to more intensive urea utilization for synthesis of microbial protein in the large intestine due to a greater energy supply.

Deterioration of body weight gain and feed utilization was found only in younger pigs fed the R-containing diet, and it was not related to any parameters of protein utilization. This may indicate a lower than calculated energy value of this diet or, which is less likely, an effect of some antinutritional factors present in $\mathrm{R}$ (as resorcinols).

The origin and level of soluble NSP used in the present study had no effect on the length and weight of the small intestine. This finding is at variance with the results of studies reported by Montagne et al. (2003) indicating the trophic effect of fibre on the gut. Both $\mathrm{P}$ level and R affected intestinal morphology, but the effects varied among the segments and parameters under study, which is in line with the general statement on the diverse effects of fibre depending on its physicochemical characteristics and level of incorporation, site of the gut, age of animals, and duration of ingestion.

In general, addition of $\mathrm{P}$ provoked less extensive modifications of all parameters except myenteron thickness than inclusion of R. Moreover, the response of many parameters to $\mathrm{P}$ was not proportional to the amount added to the diet. Both amounts of $\mathrm{P}$ had small and inconsistent effects on villi length, villi surface, crypt depth, and villi length to crypt depth ratio, parameters reflecting epithelial cell turnover rate and considered related to the digestive capacity of the small intestine. This finding is apparently not consistent with the considerable depression of ileal digestibility of protein and AA by P found in Experiment 1 . The possible explanation may be a shorter period of feeding experimental diets and younger age of pigs in digestibility experiment than in Experiment 2 when morphological parameters were determined, indicating probably some adaptation of the gut to this type of fibre. In the experiments performed on early weaned piglets, the effects of soluble fibre on gut morphology were more evident than in our study, but were also equivocal. Feeding citrus pulp in similar amounts reduced both villi length and crypt depth in Hedemann et al. (2006) experiment while feeding diet containing low viscosity methylcellulose increased villous length and crypt depth as found by McDonald et al. (2001). 
Feeding the R-containing diet had a consistent effect on crypt depth, which in all segments was greater than in the control and P-fed animals, indicating more intensive crypt-cell production. Only in the ileum was the greater crypt depth accompanied by increased villi length and mucosa thickness, which may be interpreted as a greater turnover rate of the epithelial cells.

Myenteron thickness in all segments was the only parameter which was considerably affected by $\mathrm{P}$ and was greater than on the control and R-containing diets. On all the diets, myenteron thickness was the smallest in the jejunum and the greatest in the ileum.

The possible mechanisms involved in changes in intestinal morphology by soluble fibre include increased viscosity and enhanced production of SCFA, which have a trophic effect on the epithelium (Montagne et al., 2003). In view of a different digesta viscosity between the control and low-P vs high-P diet, as discussed earlier, and small differences in the intestinal morphology in pigs fed these diets, viscosity does not seem to have a significant impact in this case. Pectin is an intensively fermented fibre stimulating production of SCFA in the large intestine. A trophic effect of SCFA was shown not only in the colon, but also in the small intestine and may explain the increase of myenteron thickness in P-fed animals.

The depth of the tunica mucosa, which is a quantitative parameter of the mucus layer, decreased gradually along the small intestine and was affected by diets in the duodenum and mid-jejunum. Pectin and R had opposite effects, since $\mathrm{P}$ fed in smaller amounts decreased the depth of the tunica mucosa (only in the duodenum), whereas $\mathrm{R}$ significantly increased this parameter in the mid-jejunum and tended to increase it in the other two segments.

Thickness of the mucus layer is modulated by erosion on the luminal side and by synthesis and secretion of mucins from specialized differentiated GC located in the epithelium. Both processes are affected by dietary factors, including fibre. It appears that insoluble fibre has a more abrasive action, while the effect of soluble fibre seems to depend on its water-holding capacity (Montagne et al., 2003).

The number of GC producing neutral and acidic mucins in villi and crypts considerably greater in the ileum than in the mid-jejunum what does not correspond with a tendency to smaller depth of tunica mucosa in the ileum and may indicate a greater erosion in this part of the intestine. Goblet cell number was affected by the type and amount of fibre in different way. Pectin fed in smaller amount decreased number of GC producing acidic mucins in crypts of the mid-jejunum and in villi of the ileum while greater amount of P increased number of GC producing neutral mucins in crypts of the ileum. Feeding $\mathrm{R}$ had similar depressive effect on number of GC producing acidic mucins in villi of the ileum as $\mathrm{P}$ fed in smaller amount. These results are partly in agreement with the study of Hademann et al. (2006) 
who found lower acidic mucin staining areas only in crypts in the mid-jejunum, ileum, and mid-colon in early weaned piglets fed a diet with citrus pectin. In contrast, acidic and neutral mucin staining areas in the small intestine were not affected by soluble NSP fed to adult pigs (Serena et al., 2008). This may indicate that the effect of fibre on secretion of mucins in the small intestine depends on the age of pigs.

Since acidic mucins protect the gut against bacterial translocation (Deplancke and Gaskins, 2001), feeding P (in smaller amounts) and R may increase the susceptibility of pigs to bacterial infection. The positive effect of the larger amount of $\mathrm{P}$ on the number of GC containing neutral mucins in crypts of the ileum is not consistent with the results of Hedemann et al. (2006), who found a similar effect in the mid-colon, but not in the ileum.

The rate of colonic mucosal protein synthesis, particularly of Thr-rich mucin protein, is considered an important factor affecting utilization of $\mathrm{Thr}$ for protein deposition in growing animals. Pectin increases the fractional synthesis rate of colonic mucosal proteins (Libao-Mercado et al., 2007) and, therefore, may enhance the total requirement for Thr and affect the metabolism of this AA.

In our study, neither of the parameters related to Thr metabolism, i.e. the evolution of postprandial free Thr level and TDG activity in the liver and pancreas, were affected by the type and level of dietary NSP. It may be therefore concluded that the small changes in tunica mucosa depth and GC type and number due to $\mathrm{P}$ and $\mathrm{R}$ did not produce evident changes in Thr metabolism.

\section{CONCLUSIONS}

Feeding pectin or rye negatively affects the ileal digestibility of protein and amino acids and provokes irregular changes in small intestinal morphology. These effects cannot be attributed to the increase of digesta viscosity as the main factor. The parameters related to threonine metabolism were not affected by nonstarch polysaccharides, probably because the requirement for this amino acid was covered factor. The parameters related to threonine metabolism are not affected by non-starch polysaccharides probably due to the covered requirement for this amino acid. 


\section{REFERENCES}

AOAC, 1990. Association of Analitycal Chemists, Official Methods of Analysis. $15^{\text {th }}$ Edition. Washington, DC

Bartelt J., Jadamus A., Wiese F., Święch E., Buraczewska L., Simon O., 2002. Apparent precaecal digestibility of nutrients and level of endogenous nitrogen in digesta of the small intestine of growing pigs as affected by various digesta viscosities. Arch. Anim. Nutr. 56, 93-107

Buraczewska L., 2001. Fibre components negatively affect ileal protein digestibility in pigs. J. Anim. Feed Sci. 10, Suppl. 1, 139-152

Buraczewska L., Buraczewski S., 1984. A note on determination of methionine and tryptophan. In: Proceeding of the $6^{\text {th }}$ International Symposium on Amino Acids. Serock (Poland). Polish Scientific Publishers, Warsaw, pp. 47-50

Buraczewska L., Święch E., Le Bellego L., 2006. Nitrogen retention and growth performance of 25 to $50 \mathrm{~kg}$ pigs fed diets of two protein levels and different ratios of digestible threonine to lysine. J. Anim. Feed Sci. 15, 25-36

Buraczewska L., Wasilewko J., Fandrejewski H., Żebrowska T., Han I.K., 1999. Formulation of pig diets according to ileal digestible amino acid content. Livest. Prod. Sci. 59, 13-24

Deplancke B., Gaskins H.R., 2001. Microbial modulation of innate defense: goblet cells and the intestinal mucus layer. Amer. J. Clin. Nutr. 73, 1131S-1141S

Hedemann M.S., Eskildsen M., Lærke H.N., Pedersen C., Lindberg J.E., Laurinen P., Bach Knudsen K.E., 2006. Intestinal morphology and enzymatic activity in newly weaned pigs fed contrasting fibre concentrations and fiber properties. J. Anim. Sci. 84, 1375-1386

Hušek P., 1991. Amino acid derivatization and analysis in five minutes. FEBS Lett. 280, 354-356

Jansman A.J.M., Smink W., van Leeuwen P., Rademacher M., 2002. Evaluation through literature data of the amount and amino acid composition of basal endogenous crude protein at the terminal ileum of pigs. Anim. Feed Sci. Tech. 98, 49-60

Kimura F.T., Miller V.L., 1957. Improved determination of chromic oxide in cow feed and feces. J. Agr. Food Chem. 5, 216

Libao-Mercado A.J., Zhu C.L., Fuller M.F., Rademacher M., Séve B., de Lange C.F.M., 2007. Effect of feeding fermentable fiber on suthesis of total and mucosal protein in the intestine of the growing pigs. Livest. Sci. 109, 125-128

McCullough J.S., Ratcliffe B., Mandir N., Carr K.E., Goodlad R.A., 1998. Dietary fibre and intestinal microflora: Effects on intestinal morphometry and crypt branching. Gut 42, 799-806

McDonald D.E., Pethick D.W., Mullan B.P., Hampson D.J., 2001. Increasing viscosity of the intestinal contents alters small intestinal structure and intestinal growth, and stimulates proliferation of enterotoxigenic Escherichia coli in newly-weaned pigs. Brit. J. Nutr. 86, 487-798

Montagne L., Pluske J.R., Hampson D.J., 2003. A review of interactions between dietary fibre and the intestinal mucosa, and their consequences on digestive health in young non-ruminant animals. Anim. Feed Sci. Tech. 108, 95-117

Mosenthin R., Sauer W.C., Ahrens F., 1994. Dietary pectin's effect on ileal and fecal amino acid digestibility and exocrine pancreatic secretions in growing pigs. J. Nutr. 124, 1222-1229

Myrie S.B., Bertolo R.F., Sauer W.C., Ball R.O., 2006. Effect of common antinutrive factors and fibrous feedstuffs in pig diets on amino acid digestibilities with special emphasis on threonine. J. Anim. Sci. 86, 609-619

NRC, 1998. Nutrient Requirements of Swine. 10 $0^{\text {th }}$ Edition. National Academy Press. Washington, $\mathrm{DC}$

Rademacher M., Sauer W.C., Jansman A.J.M., 1999. Standardized ileal digestibility of amino acids in pigs, The New System, Degussa-Hülls 
Schulze H., van Leeuwen P., Verstegen M.W.A., van der Berg J.W., 1995. Dietary level and source of neutral detergent fiber and ileal endogenous nitrogen flow in pigs. J. Anim. Sci. 73, 441448

Serena A., Hedemann M.S., Bach Knudsen K.E., 2008. Influence of dietary fiber on luminal environment and morphology in the small and large intestine of sows. J. Anim. Sci. 86, 22172227

Simpson G.J., 1998. Development of methods to improve the estimation of threonine catabolism in the growing pigs. MSc. Thesis, University of Guelph, Guelph (Canada)

StatSoft Inc., 1997. Statistica 8.0 PL for Windows, Tulsa (USA)

Souffrant W.B., 2001. Effect of dietary fibre on ileal digestibility and endogenous nitrogen lossess in the pigs. Anim. Feed Sci. Tech. 90, 93-102

Van Leeuwen P., van Kleef D., van Kempen G.J.M., Huisman J., Verstegen M.W.A., 1991. The post valve T-ceacum canulation technique in pigs applicated to determine the digestibility of amino acids in maize, groundnut and sunflower meal. J. Anim. Physiol. Anim. Nutr. 65, 185-193

Wenk C., 2001. The role of dietary fibre in the digestive physiology of the pig. Anim. Feed Sci. Tech. 90, 21-33

Zhu C.L., 2003. Effects of graded levels of dietary pectin on amino acid utilization for body protein deposition in growing pigs. MSc Thesis, University of Guelph, Guelph, Ontario (Canada) 